\title{
Tirtayatra sebagai Bentuk Wisata Religi Masyarakat Hindu di Bali
}

\author{
I Nengah Aryanatha \\ Program Studi Penerangan Agama Hindu Fakultas Dharma Duta \\ IHDN Denpasar
}

\author{
aryanathaihdn@gmail.com
}

\begin{abstract}
Various forms of travel nowadays continue to grow, one of which is religious tourism. Religious tourism is one of the phenomenon that is currently starting to populate, it proved many activities or activities associated with religious tourism such as Tirta Yatra conducted by Hindu community in Bali. In some community groups, religious tourism is often used as a monthly, annual, and routine activities. In addition to getting the calm and pleasure (refreshing), it will also gain insight into the sacred historical sites and increase awareness of gratitude for the omnipotence of God (Ida Sang Hyang Widhi Wasa). Therefore, not only the health of mind that is obtained through religious tourism, but also the reward by interpreting the tour as a worship to improve or strengthen the faith.
\end{abstract}

Keywords : Religious Tourism, Tirta Yatra.

\section{Pendahuluan}

Secara umum pariwisata merupakan suatu perjalanan yang dilakukan seseorang untuk sementara waktu yang diselenggarakan dari suatu tempat ke tempat yang lain dengan meninggalkan tempat semula dan dengan suatu perencanaan atau bukan maksud untuk mencari nafkah di tempat yang dikunjunginya, tetapi semata-mata untuk menikmati kegiatan pertamasyaan atau rekreasi untuk memenuhi keinginan yang beraneka ragam. Menurut Kodhyat (1998) pariwisata adalah perjalanan dari suatu tempat ketempat lain, bersifat sementara, dilakukan perorangan atau kelompok, sebagai usaha mencari keseimbangan atau keserasian dan kebahagian dengan lingkungan dalam dimensi sosial, budaya, alam dan ilmu. Sedangkan Gamal (2002), pariwisata didefinisikan sebagai bentuk. suatu proses kepergian sementara dari seorang, lebih menuju ketempat lain diluar tempat tinggalnya. Dorongan kepergiannya adalah karena berbagai kepentingan baik karena kepentingan ekonomi, sosial, budaya, politik, agama, kesehatan maupun kepentingan lain. Selanjutnya Burkart dan Medlik (1987) menjelaskan pariwisata sebagai suatu trasformasi orang untuk sementara dan dalam waktu jangka pendek ketujuantujuan di luar tempat di mana mereka biasanya hidup dan bekerja, dan kegiatankegiatan mereka selama tinggal di tempat-tempat tujuan itu. Menurut WTO (1999), yang dimaksud dengan pariwista adalah kegiatan manusia yang melakukan perjalanan ke dan tinggal di daerah tujuan di luar lingkungan kesehariannya. Sedangkan menurut Undang - Undang RI nomor 10 tahun 2009 tentang kepariwisataan dijelaskan bahwa wisata adalah kegiatan perjalanan yang dilakukan oleh seseorang atau sekelompok orang dengan mengunjungi tempat tertentu untuk tujuan rekreasi, pengembangan pribadi, atau mempelajari keunikan daya tarik wisata yang dikunjungi dalam waktu sementara.

Perjalanan wisata dewasa ini bukan lagi hanya terbatas dilakukan oleh kalangan kelas ekonomi mapan saja, namun masyarakat umumpun saat ini sudah menjadikan kegiatan wisata sebagai salah satu kebutuhan hidup mereka, meskipun dengan keterbatasan kemampuan mereka dengan melakukan perjalanan wisata local di daerah masing-masing, karena sesuai dengan konsepnya perjalanan wisata dapat dilakukan bila memenuhi tiga unsur yaitu : keinginan untuk berwisata, ketersediaan waktu luang, dan ketersediaan biaya yang cukup. Keinginan berwisata (refreshing) bukan semata-mata hanya pemenuhan kebutuhan jasmani (kebugaran badan fisik) semata tetapi lebih pada pemenuhan kebutuhan rohani (ketenangan jiwa dan pikiran) ditengah tuntutan pekerjaan dan rutinitas masyarakat modern saat ini.

Berbagai bentuk perjalanan wisata dewasa ini terus berkembang, salah satunya adalah wisata religi (religious tourism). Wisata religi merupakan salah satu fenomena yang saat ini mulai memasyarakat, hal itu dibuktikannya banyak aktifitas atau kegiatan yang dikaitkan dengan wisata religi tidak terkecuali kegiatan tirta yatra masyarakat Hindu di Bali. Pada beberapa kelompok masyarakat, wisata religi ini sering dijadikan sebagai kegiatan rutinan baik bulanan, tahunan dan sebagainya. Selain untuk mendapatkan ketenangan dan kesenangan (refreshing), juga akan mendapatkan wawasan tentang situs-situs bersejarah yang disucikan serta menambah kesadaran rasa syukur akan kemahakuasaan Tuhan (Ida Sang Hyang Widhi Wasa). Oleh karena itu, bukan 
hanya kesehatan pikiran saja yang didapatkan melalui wisata religi, akan tetapi juga mendapatkan pahala dengan memaknai wisata sebagai ibadah untuk meningkatkan atau mempertebal keimanan.

\section{Pembahasan \\ Konsep Pariwisata}

Pariwisata dalam arti luas adalah kegiatan rekreasi di luar domisili atau melepaskan diri dari pekerjaan rutin atau mencari suasana lain. Sebagai suatu aktivitas, pariwisata telah menjadi bagian penting dari kebutuhan dasar masyarakat modern. Pariwisata semakin berkembang sejalan perubahan-perubahan sosial, budaya, ekonomi, teknologi, dan politik.

Berdasarkan Undang-Undang Nomor 10 Tahun 2009, Wisata adalah kegiatan perjalanan yang dilakukan oleh seseorang atau sekelompok orang dengan mengunjungi tempat tertentu untuk tujuan rekreasi, pengembangan pribadi, atau mempelajari keunikan daya tarik wisata yang dikunjungi dalam jangka waktu sementara, dan Pariwisata adalah berbagai macam kegiatan wisata dan didukung berbagai fasilitas serta layanan yang disediakan oleh masyarakat, pengusaha, Pemerintah, dan Pemerintah Daerah.

Menurut Pendit (1994), pariwisata dapat dibedakan menurut motif wisatawan untuk mengunjungi suatu tempat. Jenis-jenis pariwisata tersebut adalah sebagai berikut :

a) Wisata Budaya

Yaitu perjalanan yang dilakukan atas dasar keinginan untuk memperluas pandangan hidup seseorang dengan jalan mengadakan kunjungan atau peninjauan ketempat lain atau ke luar negeri, mempelajari keadaan rakyat, kebiasaan adat istiadat mereka, cara hidup mereka, budaya dan seni mereka. Seiring perjalanan serupa ini disatukan dengan kesempatan-kesempatan mengambil bagian dalam kegiatan-kegiatan budaya, seperti eksposisi seni (seni tari, seni drama, seni musik, dan seni suara), atau kegiatan yang bermotif kesejarahan dan sebagainya. Salah satu daerah di Indonesia yang mengembangkan pariwisata budaya adalah Bali. Sesuai dengan Perda Provinsi Bali Nomor 3 Tahun 1991 mendefinisikan pariwisata budaya sebagai : jenis kepariwisataan yang dalam perkembangan dan pengembangannya menggunakan kebudayaan daerah Bali yang dijiwai oleh agama Hindu yang merupakan bagian dari kebudayaan nasional sebagai potensi dasar yang dominan, yang di dalamnya tersirat satu cita-cita akan adanya hubungan timbal balik antara pariwisata dan kebudayaan sehingga keduanya meningkat secara serasi, selaras, dan seimbang.

b). Wisata Bahari

Jenis wisata ini banyak dikaitkan dengan kegiatan olah raga di air, lebih-lebih di danau, pantai, teluk, atau laut seperti memancing, berlayar, menyelam sambil melakukan pemotretan, kompetisi berselancar, balapan mendayung, melihat-lihat taman laut dengan pemandangan indah di bawah permukaan air serta berbagai rekreasi perairan yang banyak dilakukan didaerah-daerah atau negara-negara maritim, di Laut Karibia, Hawaii, Tahiti, Fiji dan sebagainya. Di Indonesia banyak tempat dan daerah yang memiliki potensi wisata maritim ini, seperti misalnya Pulau-pulau Seribu di Teluk Jakarta, Danau Toba, pantai Pulau Bali dan pulau-pulau kecil disekitarnya, taman laut di Kepulauan Maluku dan sebagainya. Jenis ini disebut pula wisata tirta.

c). Wisata Cagar Alam (Taman Konservasi)

Untuk jenis wisata ini biasanya banyak diselenggarakan oleh agen atau biro perjalanan yang mengkhususkan usaha-usaha dengan jalan mengatur wisata ke tempat atau daerah cagar alam, taman lindung, hutan daerah pegunungan dan sebagainya yang kelestariannya dilindungi oleh undang-undang. Wisata cagar alam ini banyak dilakukan oleh para penggemar dan pecinta alam dalam kaitannya dengan kegemaran memotret binatang atau marga satwa serta pepohonan kembang beraneka warna yang memang mendapat perlindungan dari pemerintah dan masyarakat. Wisata ini banyak dikaitkan dengan kegemaran akan keindahan alam, kesegaran hawa udara di pegunungan, keajaiban hidup binatang dan marga satwa yang langka serta tumbuh-tumbuhan yang jarang terdapat di tempat-tempat lain. Di Bali wisata Cagar Alam yang telah berkembang seperti Taman Nasional Bali Barat dan Kebun Raya Eka Karya.

d). Wisata Konvensi

Berbagai negara pada dewasa ini telah membangun wisata konvensi atau yang lebih dikenal dengan wisata MICE (Meeting, Incentive, Convention, Exhibition) ini dengan menyediakan fasilitas bangunan dengan ruangan-ruangan tempat bersidang ataupun ruang pameran bagi para peserta suatu konfrensi, musyawarah, konvensi atau pertemuan lainnya baik yang bersifat nasional maupun internasional. Indonesia mempunyai Balai Sidang Senayan di Jakarta untuk tempat penyelenggaraan sidang-sidang pertemuan besar dengan perlengkapan modern, serta Bali sebagai destinasi wisata internasional telah memiliki Bali International Convention Center (BICC) di Nusa Dua. Berbagai Biro Perjalanan Wisata yang melayani usaha wisata MICE ini terus berusaha dengan keras untuk menarik perusahaan, organisasi atau badanbadan nasional maupun internasional untuk mengadakan persidangan mereka di pusat konvensi 
ini dengan menyediakan fasilitas akomodasi dan sarana pengangkutan dengan harga reduksi yang menarik serta menyajikan program-program atraksi yang menggiurkan.

e). Wisata Pertanian (Agrowisata)

Sebagai halnya wisata industri, wisata pertanian ini adalah pengorganisasian perjalanan yang dilakukan ke proyek-proyek pertanian, perkebunan, ladang pembibitan dan sebagainya dimana wisatawan rombongan dapat mengadakan kunjungan dan peninjauan untuk tujuan studi maupun melihat-lihat keliling sambil menikmati segarnya tanaman beraneka warna dan suburnya pembibitan berbagai jenis sayur-mayur dan palawija di sekitar perkebunan yang dikunjungi.

f). Wisata Berburu

Jenis ini banyak dilakukan di negeri-negeri yang memang memiliki daerah atau hutan tempat berburu yang dibenarkan oleh pemerintah dan digalakan oleh berbagai agen atau biro perjalanan. Wisata buru ini diatur dalam bentuk safari buru ke daerah atau hutan yang telah ditetapkan oleh pemerintah negara yang bersangkutan, seperti berbagai negeri di Afrika untuk berburu gajah, singa, ziraf, dan sebagainya. Di India, ada daerah-daerah yang memang disediakan untuk berburu macan, badak dan sebagainya, sedangkan di Indonesia, pemerintah membuka wisata buru untuk daerah Baluran di Jawa Timur dimana wisatawan boleh menembak banteng atau babi hutan.

g). Wisata Ziarah

Jenis wisata ini sedikit banyak dikaitkan dengan agama, sejarah, adat istiadat dan kepercayaan umat atau kelompok dalam masyarakat. Wisata ziarah banyak dilakukan oleh perorangan atau rombongan ke tempat-tempat suci, ke makam-makam orang besar atau pemimpin yang diagungkan, ke bukit atau gunung yang dianggap keramat, tempat pemakaman tokoh atau pemimpin sebagai manusia ajaib penuh legenda. Wisata ziarah ini banyak dihubungkan dengan niat atau hasrat sang wisatawan untuk memperoleh restu, kekuatan batin, keteguhan iman dan tidak jarang pula untuk tujuan memperoleh berkah dan kekayaan melimpah. Dalam hubungan ini, orang-orang Khatolik misalnya melakukan wisata ziarah ini ke Istana Vatikan di Roma, orangorang Islam ke tanah suci, orang-orang Budha ke tempat-tempat suci agama Budha di India, Nepal, Tibet dan sebagainya. Di Indonesia banyak tempat-tempat suci atau keramat yang dikunjungi oleh umat-umat beragama tertentu, misalnya seperti Candi Borobudur, Prambanan, Pura Basakih di Bali, Sendangsono di Jawa Tengah, makam Wali Songo, Gunung Kawi, makam Bung Karno di Blitar dan sebagainya. Banyak agen atau biro perjalanan menawarkan wisata ziarah ini pada waktu-waktu tertentu dengan fasilitas akomodasi dan sarana angkuatan yang diberi reduksi menarik ke tempat-tempat tersebut di atas.

Sesungguhnya daftar jenis-jenis wisata lain dapat saja ditambahkan di sini, tergantung kapada kondisi dan situasi perkembangan dunia kepariwisataan di suatu daerah atau negeri yang memang mendambakan industri pariwisatanya dapat meju berkembang. Pada hakekatnya semua ini tergantung kepada selera atau daya kreativitas para ahli profesional yang berkecimpung dalam bisnis industri pariwisata ini. Makin kreatif dan banyak gagasan-gagasan yang dimiliki oleh mereka yang mendedikasikan hidup mereka bagi perkembangan dunia kepariwisataan di dunia ini, makin bertambah pula bentuk dan jenis wisata yang dapat diciptakan bagi kemajuan industri ini, karena industri pariwisata pada hakikatnya kalau ditangani dengan kesungguhan hati mempunyai prospektif dan kemungkinan sangat luas, seluas cakrawala pemikiran manusia yang melahirkan gagasan-gagasan baru dari waktu-kewaktu. Termasuk gagasan-gagasan untuk menciptakan bentuk dan jenis wisata baru seperti wisata religi (religius tourism) misalnya.

\section{Konsep Wisata Religi (Religious Tourism)}

Istilah Religi secara harfiah berarti kepercayaan akan adanya kekuatan akodrati di atas manusia (Gayatri, 1994). Banyak orang menyamakan religi sebagai agama, pendapat tersebut tidak dapat disalahkan walaupun pada dasarnya pembicaraan tentang religi jauh lebih luas jangkauannya dalam lingkup agama, karena religi sendiri pada dasarnya merupakan suatu fenomena pada segala aspek yang ada di luar kekuatan manusia berupa kepercayaan akan kehidupan lain dan mahlukmahluk gaib (Gayatri, 1994). Pada awalnya konsep religi muncul berupa:

1. Dinamisme (percaya kepada kekuatan alam)

Gejala tersebut ada karena pemikiran spekulatif pada saat manusia menghadapi suatu yang membuat mereka tidak berdaya, biasanya hal ini ditimbulkan oleh gejala-gejala alam yang tidak dapat dihindari oleh manusia dan manusia akan tersugesti pada saat tindakan spekulasi tersebut mengalami kebenaran, walaupun dengan cara tidak sengaja, contohnya pemujaan terhadap matahari, angin, api, pohon besar dan lain-lain.

2. Animisme (percaya terhadap kekuatan roh nenek moyang)

Gejala ini muncul karena pemujaan terhadap suatu indiyidu yang menjadi pemimpin suatu kelompok secara berlebihan, dimana setelah individu tersebut meninggal maka para pengikut (pemujanya) menganggap arwah dan kekuatan spiritualnya akan tetap ada dan wajib untuk disembah. 
Menurut Koentjaraningrat (2004), religi sebagai kepercayaan hidup manusia mempunyai beberapa unsur yang terdiri dari:

- Emosi Keagamaan

- Kepercayaan

- Upacara Keagamaan

- Kelompok Keagamaan

Pada bagian lain Koentjaraningrat (2004), menyatakan bahwa berbicara tentang agama sebagai suatu sistem didalamnya terkandung lima aspek penting diantaranya adalah:

1). Emosi keagamaan atau getaran jiwa yang menyebabkan manusia menjalankan kelakuan keagamaan.

2). Sistem kepercayaan atau bayangan.

3). Bayangan manusia tentang bentuk dunia alam gaib, hidup mati dan sebagainya .

4) Sistem upacara keagamaan yang bertujuan mencari hubungan dengan dunia gaib berdasarkan atas sistem kepercayaan.

5). Sistem peralatan ritus upacara keagamaan sebagai perlengkapan kelompok keagamaan atau kesatuan-kesatuan sosial yang mengkonsepsikan serta mengaktifkan agama beserta sistem upacara-upacara keagamaannya atas dasar kelima unsur-unsur tersebut pembahasan mengenai perubahan budaya khususnya sistem religi akan difokuskan.

Vukonic (1996) mendefinisikan religious tourism sebagai berikut : "Religious tourism as consisting of a range of spiritual sites and associated services, which are visited for both secular and religious reasons" Pengertian tersebut menunjukkan bahwa wisata keagamaan dapat terjadi bukan hanya karena alasan keagamaan namun ada hal lain juga yang menjadi motivasi seseorang melakukan perjalanan wisata keagamaan. Selain itu, Santos (2003) menyebutkan lima karakteristik yang dimiliki oleh religious tourism, yaitu sebagai berikut :

a. Voluntary, temporary and unpaid travel.

b. Motivated by religion.

c. Supplemented by other motivations.

d. The destination is a religious site (local, reginoal, national or international status).

e. Travel to the destination is not a religious practice.

Karakteristik yang disebutkan di atas menjadi syarat utama sebuah perjalanan dikategorikan sebagai wisata religi.

Beberapa dekade belakangan ini, antusiasme "religious tourism" meningkat tajam. Hal ini dikarenakan "religious tourism" menawarkan "double satisfaction" atau kepuasan ganda. Mereka bisa menikmati perjalanan wisata, mengunjungi bangunan/tempat suci, bertemu orang-orang baru, mengenal budaya lokal, dan lain-lain. Pengalaman ini membawa peserta "religious tourism" mendapatkan kepuasan berwisata. Di sisi lain, mereka juga mengharapkan kepuasan batin/spiritual dengan pengalaman iman dengan menarik diri sementara waktu dari aktivitas harian mereka seperti bekerja dan belajar untuk bergabung dengan peserta lainnya berbagi mengenai pengalaman hidup dan mendalami lebih jauh agama mereka melalui kunjungan ke situs-situs suci. Fenomena "religious tourism" membuat banyak tempat-tempat suci di seluruh penjuru dunia kebanjiran pengunjung. Tidak hanya tempat-tempat suci, berbagai aktivitas budaya yang berakar pada kepercayaan dan keagamaan juga menjadi event yang ditunggu-tunggu.

\section{Konsep Wisata Religi Menurut Agama Hindu}

Agama Hindu mengajarkan banyak cara untuk mendekatkan diri dengan Tuhan, ada jalan yoga, meditasi, beryadnya, penguasaan ilmu pengetahuan, dll. Dari sekian banyak cara yang ada, salah satu yang paling mudah dan bisa dilakukan oleh setiap orang adalah dengan jalan melaksanakan Wisata Religi yang dalam Agama Hindu sering disebut dengan Tirtha Yatra , Dharma Yatra, Vita Sagara.

Tirtha Yatra atau perjalanan suci, merupakan suatu kegiatan keagamaan untuk meningkatkan kehidupan spiritual (kerohanian) dengan cara mengunjungi tempat tempat suci kemudian melakukan persembahyangan, melakukan meditasi dan japa. Dharma Yatra, perjalanan suci bagi Rohaniwan untuk membabarkan ajaran dharma ketempat tempat yang dianggap suci, Vita Sagara melakukan perjalanan suci dalam bentuk mengarungi lautan/samudra.

Penjelasan tentang Tirtha Yatra, Dharma Yatra, Vita Sagara diuraikan secara jelas di dalam Sarassamuscaya. Berikut ini penjelasan tentang Tirtha Yatra dalam Sarasamuscaya :

Akkrodanasca rajendra satya silo drdawratah, atmopamasca bhutesu, sa tirthapalam asnute (Sarasamuscaya.277 dalam Kajeng, 1997)

artinya : 
Ada orang seperti ini prilakunya, tidak diliputi oleh kemarahan, benar-benar satya teguh pada brata, kasih sayang terhadap semua mahluk, orang yang demikian prilakunya, pahala Tirtha Yatra kelak diperolehnya. Tirtha Yatra maksudnya berlkeliling dengan niat suci mengunjungi tempattempat suci.

Sada daridrair api hi sakhyam praptum naradhipa,

tirthabhigamanam punyam yakner api wisiyate ( Sarasamuscaya.279 dalam Kajeng, 1997)

Artinya :

Sebab keutamaan Tirtha Yatra amat suci lebih utama dari melaksanakan yadnya, dapat dilakukan oleh orang miskin.

Dari kutipan tersebut diatas, Tirtha Yatra jelas mempunyai kedudukan yang amat penting dalam ajaran agama Hindu. Tirtha Yatra lebih utama dari melaksanakan Yadnya (upacara) dan hal ini bisa dilakukan oleh siapa saja, termasuk orang orang miskin. Sebaliknya orang kaya bila tidak pernah berpuasa, tidak pernah mandi ditempat suci, orang yang demikian disebut orang miskin ( Sarasamuscaya 278), miskin dibidang aktivitas rohani.

Tempat- tempat dijadikan Tirtha Yatra adalah tempat tempat suci yang ada petirtan terutama yang memiliki nilai sejarah dan diyakini kesuciannya seperti Pura di Bali atau Mandir dan Kuil di India). Di Bali kita mengenal ada Pura yang tergolong Sad Kahyangan dan Dang Kahyangan atau Kahyangan Jagat, seperti ; Pura Besakih, Pura Uluwatu, Pura Tanah Lot, Pura Lempuyang, Pura Tampak Siring, Pura Batur, Pura Pucak Penulisan, Pura Sakenan, dan lain-lain. Demikian juga didaerah lainnya seperti Candi Prambanan, Candi Ceto, di Jawa Tengah, Gunung Bromo di Jawa Timur. Pura Gunung Salak di Bogor, di Lombok Pura Suranadi, Pura Narmada, dan Pura Lingsar. antara lain :

Adapun makna dan manfaat Tirtha Yatra, Dharma Yatra dan Vita Sagara disebutkan

1. Dengan Tirtha Yatra kita dapat meningkatkan Sradha. Kita datang menuju tempat suci yang jauh melaksanakan bhakti, sembahyang, japa, meditasi dan pembacaan kitab suci dan Dharmagita.

2. Dengan Tirtha Yatra terjadilah proses penyegaran kembali terhadap mental dan fisik kita yang sebelumnya mungkin jenuh akibat rutinitas, melakukan pekerjaan sehari hari.

3. Dengan Tirtha Yatra memperluas cakrawala, kita mengagumi, betapa besar dan Maha Agung Ida Sang Hnyang Widhi sebagai Pencipta, meningkatkan kesucian sehingga kita dapat lebih mendekatkan diri dengan Tuhan.

4. Dengan membaca kitab suci, menyanyikan Dharmagita, japa, meditasi akan meningkatkan pemahaman kita terhadap nilai nilai yang terkandung dalam ajaran agama Hindu.

Demikian sekilas gambaran tentang Wisata Religi yang dalam Agama Hindu disebut dengan istilah Tirtha Yatra, Dharma Yatra dan Vita Segara atau sering diartikan untuk melakukan perjalanan suci sebagai upaya pendekatan diri atau wujud bhakti kepada Ida Sang Hyang Widhi Wasa/Tuhan Yang Maha Esa yang bertujuan untuk menyerap nilai nilai spritual karena diyakini tempat tersebut mampu mengantarkan vibrasi kesucian pada setiap orang yang melaksanakannya.

\section{Penutup}

Berkembangnya pariwisata di Indonesia, wisatawan bergerak dari daerah asalnya menuju ke suatu daerah tujuan wisata, dari suatu lingkungan masyarakat tertentu masuk ke lingkungan masyarakat lain yang banyak berbeda adat-istiadatnya, the way of life, agama, atau kepercayaan yang dianutnya dan bahkan bertolak belakang dengan kebiasaan hidup setempat, dapat membuat sektor pariwisata menjadi sesuatu yang dianggap peka terhadap lingkungan, baik lingkungan alam maupun lingkungan sosial budaya.

Perda No. 2 Tahun 2012 telah menyiratkan bahwa Kepariwisataan Budaya Bali adalah kepariwisataan Bali yang berlandaskan kepada Kebudayaan Bali yang dijiwai oleh ajaran Agama Hindu dan falsafah Tri Hita Karana sebagai potensi utama dengan menggunakan kepariwisataan sebagai wahana aktualisasinya, sehingga terwujud hubungan timbal-balik yang dinamis antara kepariwisataan dan kebudayaan yang membuat keduanya berkembang secara sinergis, harmonis 
dan berkelanjutan untuk dapat memberikan kesejahteraan kepada masyarakat, kelestarian budaya dan lingkungan. Salah satu bentuk implementasi pengembangan kepariwisataan budaya Bali adalah dengan mengembangkan wisata Tirta Yatra sebagai wisata religius, dimana jenis wisata ini bertujuan untuk mendapatkan ketenangan batin dan kesenangan (refreshing), serta untuk mendapatkan wawasan tentang situs-situs bersejarah yang disucikan serta menambah kesadaran rasa syukur akan kemahakuasaan Tuhan (Ida Sang Hyang Widhi Wasa).

\section{Daftar Pustaka}

Gayatri, Arum. 1994. Antropologi Budaya. Bandung: Rosdakarya.

Kajeng, I Nyoman.(1997). Sarasamuscaya. Jakarta: Hanuman Sakti

Koentjaraningrat (2004), religi sebagai kepercayaan hidup

Parwata, YB. 2012. Konsep Wisata Religi Menurut Agama Hindu. https://kemenag.go.id/file/dokumen/KONSEPWISATARELEGIHINDU.doc

Pendit, I Nyoman, S. 1994. Ilmu Pariwisata, Sebuah Pengantar Perdana. Jakarta: PT Pradnya Paramita.

Peraturan Daerah Provinsi Bali Nomor 2 Tahun 2012 tentang Kepariwisataan Budaya Bali.

Pitana, I Gede. 2005. Sosiologi Pariwisata, Kajian sosiologis terhadap struktur, sistem, dan dampak-dampak pariwisata. Yogyakarta: Andi Offset.

Radhakrisnan. S, 2003. Religion and Society. Denpasar: Program Magister Ilmu Agama dan Kebudayaan Universitas Hindu Indonesia.

Richard King. 2001 Agama, Orientalisme, dan Poskolonialisme; sebuah kajian tentang pertelinkahan Antara Rasionalitas dan Mistik. Yogyakarta: Qalam.

Ritzer, George. 2007. Teori Sosiologi Modern. Jakarta: Kencana.

Titib, I Made. 2003 Teologi dan Simbol-Simbol dalam Agama Hindu. Surabaya:Paramita.

Undang-Undang RI Nomor 10 Tahun 2009 Tentang Kepariwisataan.

Vukonic, Boris. 1996. Tourism and Religion. British: Pergamon.

Yoeti, Oka..1997.Perencanaan dan Pengembangan Pariwisata.Jakarta: PT Pradnya Paramita.

Internet :

https://filokaliatour.wordpress.com/about/catatan-filokalia/religious tourism/pilgrimage-danreligious-tourism/

http://gamabali.com/kitab-sarasamuscaya/

http://mangihot.blogspot.co.id/2016/11/konsep-wisata-religi-menurut-agama-hindu.html 